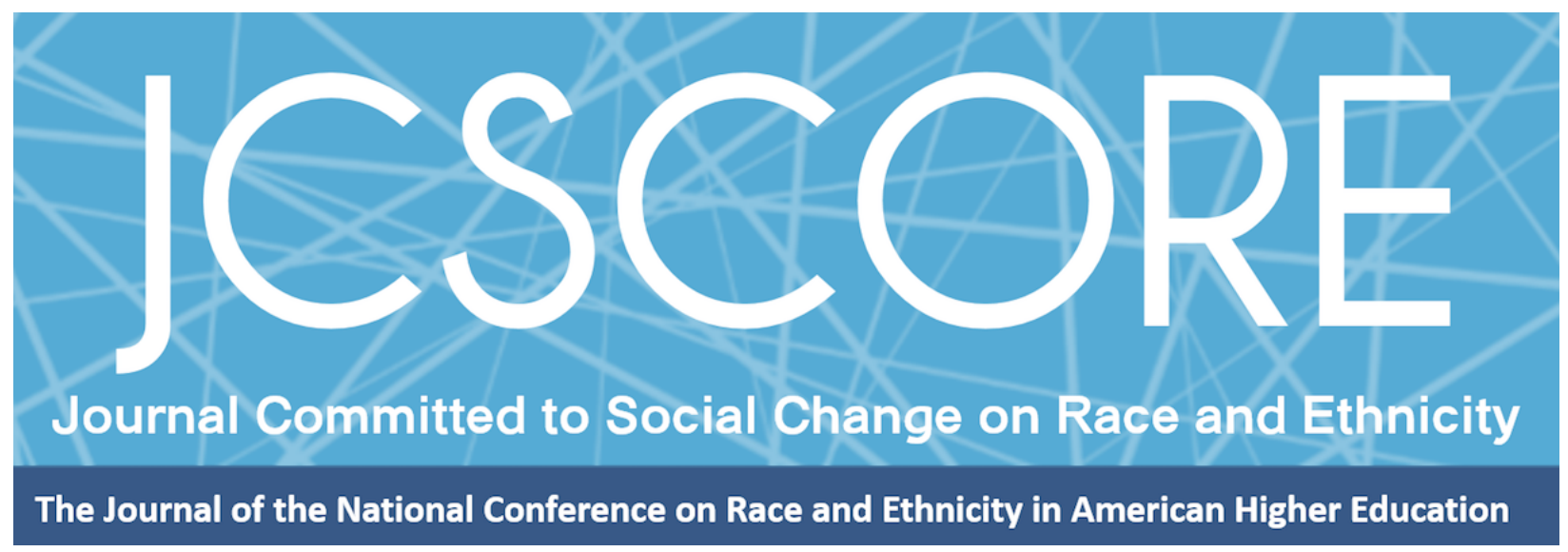

\title{
DISABILITY JUSTICE, WHITE SUPREMACY, AND HARM REDUCTION PEDAGOGY: ENACTING ANTI-RACIST CRIP TEACHING
}

Samuel Z. Shelton

Oregon State University

Journal Committed to Social Change on Race and Ethnicity

Volume 6, Issue 1 | 2020

Copyright and Open Access

(c) 2020 Samuel Z. Shelton

\section{(c) (i) (2)}

This work is licensed under a Creative Commons Attribution-NonCommercial-ShareAlike 4.0 International License. Permission of the authors is required for distribution and for all derivative works, including compilations and translations. Quoting small sections of text is allowed as long as there is appropriate attribution and the article is used for non-commercial purposes.

The Journal Committed to Social Change on Race and Ethnicity (ISSN 2642-2387) is published by the National Conference on Race and Ethnicity (NCORE), a production of the University of Oklahoma, in partnership with the University of Oklahoma Libraries. 


\title{
Disability Justice, White Supremacy, and Harm Reduction Pedagogy: Enacting Anti-Racist Crip Teaching
}

\author{
Samuel Z. Shelton \\ Oregon State University
}

\begin{abstract}
In this personal narrative, I reflect on how I have approached teaching about and for disability justice as a White crip feminist educator. I focus on how I have attempted to be accountable for my Whiteness in my teaching about an activist framework and movement grounded in the lived experiences of queer and trans disabled people of color (Sins Invalid, 2016). Towards this task, I describe my effort to enact what I term a harm reduction pedagogy or an approach to teaching that acknowledges the ongoing violence of whiteness and my participation in it while simultaneously striving to minimize the harm students of color experience in my courses. In the second section of this paper, I describe my process of accountability planning in which I anticipate possibilities for harm and prepare myself to respond to them prior to the moments when they happen.
\end{abstract}

The critical, intersectional framework of disability justice that has been advanced by such theorists and movement builders as Patty Berne (Sins Invalid, 2016), Mia Mingus (2014, 2017), Leah Lakshmi Piepzna-Samarasinha (2018), and others has forever interrupted my approach to teaching and learning, as well as my life more generally. As a multiply disabled, queer, and trans feminist educator, I found a restorative and transformative grounding in disability justice - a grounding that I could not find in the academic spaces of disability studies or more mainstream disability rights movements, for these spaces too often lack dedication to intersectionality and too often perpetuate harm against my other identities and social positions. Since its appearance in the 1980s and 1990s, disability studies in the U.S. has been complicit in queerphobia and transphobia, settler colonialism, white supremacy, and heteropatriarchy, and it must do more to actively refuse these complicities (Bell, 2017; Meekosha, 2011; Piepzna- 
Journal Committed to Social Change on Race and Ethnicity | Volume 6, Issue 1 | 2020

Samarasinha, 2018; Slater \& Lilliard, 2018). Disability justice, while not perfect or singular, begins with the most impacted and marginalized disabled folk, and it intentionally recognizes how experiences of disability oppression are interdependent with experiences of oppression along other axes of power and difference (Lewis, 2019; Mingus, 2011a). It is within this recentering that I can identify much pedagogical possibility.

The sense of grounding I have found in disability justice is not just as a haven to celebrate the different pieces of my being that are often kept apart, but also to practice accountability for my systemic and structural advantages, especially related to my Whiteness and, particularly, as a critical, feminist educator. Too much of the scholarship exploring disability and pedagogy still centers around single axis thinking that overlooks the intersectionality of identities, experiences, and needs. As a White crip, I acknowledge and strive to respond to the need for more intentional and nuanced conversations about how to enact cross-racial solidarity and Indigenous-led alliance when teaching about, with, and from disability (Price, 2011a). Practicing intersectional, anti-racist, decolonial disability justice pedagogy involves questioning the core assumptions guiding scholarship in disability studies and pedagogies in order to center people of color and create opportunities for resisting white supremacy and settler colonialism as they manifest in learning spaces and educational institutions. For racially advantaged teachers, this undertaking must be one of self-reflection, ongoing emotional labor, and active recognitions and refusals of dominance. We must be willing to reconsider how we define access(ibility) in the classroom, especially in terms of how our definition promotes the supremacy of white, western, settler bodyminds. The task before 
Journal Committed to Social Change on Race and Ethnicity | Volume 6, Issue 1 | 2020

us is one of honesty and humility in which we must learn to value the presence of racialized people above our own comfort.

In this personal narrative, I reflect on how I have approached teaching about and for disability justice as a White crip feminist educator. I focus on how I have attempted to be accountable for my whiteness in my teaching about an activist framework and movement grounded in the lived experiences of queer and trans disabled people of color (Sins Invalid, 2016). Towards this task, I describe my effort to enact what I term a harm reduction pedagogy, or an approach to teaching that acknowledges the ongoing structural violence of whiteness and my participation in it while simultaneously striving to minimize the harm students of color experience in my courses. Harm reduction, in this context, is a matter of caring for racially marginalized and disadvantaged students through my ongoing attention to accountability in all aspects of teaching/learning, a big part of which is striving to engage myself, my White students, and my colleagues in the work of unlearning and refusing white supremacy. In the second section of this paper, I describe my process of accountability planning in which I anticipate possibilities for harm and prepare myself to respond to them prior to the moments when they happen. Accountability planning is not about having all the answers or developing rigid responses that ignore context; rather, it is a tool for practicing accountability as a habit of defying internalized dominance by reversing the invisibility and familiarity of whiteness.

\section{Crip Teaching, Radical Love, and Harm Reduction Pedagogy}

As with race and ethnicity, disability is socially, politically, and historically constituted within a context of extensive inequity and injustice (Garland-Thompson, 
Journal Committed to Social Change on Race and Ethnicity | Volume 6, Issue 1 | 2020

2002). Disability is embodied and enminded, or connected to normative expectations about how our bodyminds should look and function. Yet, the meanings assigned to disability and the understandings we have of it grow out of our relationships and our interactions with other people, as well as our exposure to competing discourses (Kafer, 2013). Thus, disability oppression is a social and political construction, even as the "difference" of disability appears to be, and often is, located in our bodyminds (Clare, 1999). For example, chronic pain, chronic sickness, and mental impairment lead me to experience and inhabit my bodymind in a particular way that breaks from expectation. I am surely different from more enabled people, but while my bodymind does cause me pain and suffering, it is not the major source of disability oppression in my life. Rather, the systems and structures that malign my disabled bodymind, that refuse to make space for my access needs, and that compel me to "overcome" my disabilities or seek out a "cure" so that I can conform to an imagined ideal - these systems and structures are the sources of disability oppression, for they underlie the crisis of belonging and barriers to life that are common among disabled peoples (Clare, 2017; Levins Morales, 2013), including disabled teachers and students.

Dominant interpretations of disability promoting disability oppression are historically interwoven with white supremacy, settler colonialism, capitalism, and heteropatriarchy (Hedva, 2016; Mingus, 2011a; Sins Invalid, 2016). Lewis (2019) offers a working, community-grounded definition of ableism as a "system that places value on people's bodies and minds based on societally constructed ideas of normalcy, intelligence and excellence. These constructed ideas of normalcy, intelligence and excellence are deeply rooted in anti-Blackness, eugenics and capitalism" (para. 3). 
Journal Committed to Social Change on Race and Ethnicity | Volume 6, Issue 1 | 2020

Similarly, Patricia Berne argues that disability oppression is bound up with "the massive colonial project of Western European expansion" (Sins Invalid, 2016, p. 18). Moreover, Mia Mingus (2011b) argues that ableism is a foundational system of power that "set the stage" for many other systems, structures, and practices of domination, such as eugenics, scientific racism, murder, and slavery. In terms of education, Margaret Price (2011b) shows how the rhetorics of mental disability contribute to ongoing segregation and racialization within academic and learning spaces, such as through the disproportionate diagnosis of learning disabilities among students of color. Each of these theorists demonstrate why discussions about white supremacy and disability oppression must be simultaneous, for these systems bolster and interlock with one another. Ultimately, unmaking white supremacy cannot occur without meaningfully pursuing disability justice, and vice versa.

In recognizing this critical intersectionality, I am making a particular claim that crip teaching grounded in disability justice is (1) a substantive expression of radical love across race and solidarity with students of color and (2) the authentic acceptance of our responsibility to consistently oppose white supremacy. Anything less than an intentionally and explicitly anti-racist pedagogy does not promote the vision of disability justice because it neglects several of the core principles expressed in this framework, such as intersectionality, cross-movement solidarity, collective access, and collective liberation (Mingus, 2014; Sins Invalid, 2016). Leah Lakshmi Piepzna-Samarasinha (2018) writes about the centering of access as an act of radical love for crip bodyminds because access reimagines the conditions of our togetherness; likewise, Mia Mingus (2011a) develops the concept of access intimacy to encapsulate the "kind of eerie 
Journal Committed to Social Change on Race and Ethnicity | Volume 6, Issue 1 | 2020

comfort" disabled people can feel when someone else "gets" our access needs (para. 4). Yet, what these authors make clear as well, that White disabled teachers often neglect to understand, is that radical love for crip students cannot become the reality if we are also not actively working to love students of color. Bettina Love (2019) writes, "To love all children, we must struggle together to create the schools we are taught to believe are impossible: Schools built on justice, love, joy, and anti-racism" (para. 12).

Until White crip educators unmake our complicity in white supremacy and settler colonialism, our crip students of color will not feel welcome in our classes because we will not be teaching in a manner that represents their experiences or encourages their presence. We will not be acting toward them with radical love and solidarity. The kind of love and solidarity that disability justice demands of White crip teachers goes beyond mere diversity or inclusion, which, much like multiculturalism, are once radical ideas transformed into neoliberal concepts that predictably reinforce rather than dismantle white supremacy (Kandaswamy, 2007). While disability justice does make it necessary and urgent for teachers to prioritize the experiences and needs of disabled people of color, including disabled Indigenous people, how we go about shifting our priorities is an equally important consideration.

Beyond inclusion, disability justice requires us to be attentive to the racialization of disability oppression and the impact white supremacy has on all disabled peoples. Enacting anti-racist disability justice pedagogy entails engaging students in critical thinking about how the ways we are habituated to know disability today - its appearances, representations, categorizations, and incarcerations - have been racially coded and distributed. Indeed, it is urgent that white supremacy be theorized down to 
Journal Committed to Social Change on Race and Ethnicity | Volume 6, Issue 1 | 2020

the very foundations of disability, for it is certainly always present (Lewis, 2019; Piepzna-Samarasinha, 2018). For example, when introducing disability and disability justice to a new class, I often ask students to visualize disability, either in their minds or drawn out on a piece of paper. In my experience, students disproportionately imagine disabled people as White, along with other stereotypes (e.g., almost always in a wheelchair). From this imagining, we then begin to discuss some of their presumptions in order to open up space for thinking about disability in a more expansive way. I will also typically begin a class with a reading or quote that talks about ableism in relation to race and other sites of difference, such as the Lewis (2019) quote above.

Loving disabled students of color for White crip educators demands moving against the grains of white supremacy, moving against the familiarities and comforts afforded by whiteness in the hope of arriving at something more substantive and collectively accessible. We do this by making whiteness both visible and questionable in the intellectual spaces where its power has become unremarkable and normalized. If we are truly committed to an anti-racist disability justice pedagogy, then it is our shared responsibility to contribute to the formation of learning spaces in which the theories, critiques, and resistant actions of disabled people of color are actually taken seriously not as a "special topic" in the curriculum, but as a core pillar of understanding. In practice, taking these things seriously means refusing to teach "White disability studies" (Bell, 2017, p. 406) and disability theorists who are not actively practicing accountability for their race. It means working with our students to ensure that their learning about disability represents a wide and multi-dimensional range of disabled peoples' experiences and attending to the historical collisions and entangled genealogies of 
Journal Committed to Social Change on Race and Ethnicity | Volume 6, Issue 1 | 2020

disability oppression and White supremacy, especially as they affect us today. Taking seriously the lives of disabled people of color is a primary foundation of solidarity, and it is the essential method by which disability justice makes itself meaningful and relevant beyond Whiteness.

Learning to practice anti-racist teaching for disability justice must always begin with reflection towards self-awareness. My first task as a White crip educator is always to examine my own positionality relative to the people, histories, and social issues I am teaching about. Loving disabled students of color means comprehending how white supremacy has pulled me out of just relationship with them, as well as how I have allowed myself to be invested in narratives of my racial superiority, as all White people inevitably do. Based upon this ongoing self-reflection, I am responsible for figuring out how to reposition myself mentally, emotionally, and spiritually such that I can pursue a new mode of being that is cognizant of my racial advantage and committed to practicing alliance and racial humility. This self-reflective effort is the responsibility of all White educators, for in holding white privilege, we carry the burden of finding ways to transform our power from dominance to mutual empowerment. Further, because educational institutions across the U.S. and even transnationally construct the part of educator as one of authority (Freire, 1970/2000; hooks, 1994), it becomes even more pressing for White crip educators to contemplate the implications, possibilities, and limitations of our presence.

The responsibilities I have just described comprise the core of what I refer to as a harm reduction pedagogy, or a critical approach to teaching that acknowledges the continual presence and possibilities of harm while actively striving to minimize the harm 
Journal Committed to Social Change on Race and Ethnicity | Volume 6, Issue 1 | 2020

experienced by disadvantaged students in our classrooms. It is a pedagogy that prioritizes love and respect over carceral practices of control and eradication (Annamma \& Handy, 2019). Emi Koyama (2001) writes that "[h]arm reduction is a philosophy first developed by people organizing against HIVIAIDS crisis and other health issues among injection drug users" (para. 2). Notably, the philosophy of harm reduction is transformative and anti-carceral. The Harm Reduction Coalition (cited in Koyama, 2001) writes that the harm reduction "approach stands in stark contrast to the law enforcement efforts to criminalize and prosecute drug use as well as to the medical community's efforts to pathologize it" (para. 3, point 8). I value and seek to inhabit a practice of harm reduction because this philosophy (1) prioritizes healing and safety above carceral punishment and revenge, (2) strives to understand and resolve the underlying causes of harm rather than merely discipline individuals for responding to their circumstances, and (3) has immediate and historical connections to multiple impacted communities, including both disability communities and communities of color, as well as queer and trans communities, poor or working-class communities, and sex worker communities. Harm reduction is a way of keeping people alive and cared for in a world that too often turns against them.

I view harm reduction as part of my broader effort to promote transformative learning in the direction of healing and social justice; for me, harm reduction is inseparable from the practice of accountability. Harm reduction in higher education acknowledges that the majority of colleges and universities in this nation were constructed to support White, settler power and that these institutions as a whole continue to reproduce White supremacy through their exploitation and devaluation of 
Journal Committed to Social Change on Race and Ethnicity | Volume 6, Issue 1 | 2020

students and teachers of color (Ahmed, 2017; Duncan, 2014; Ferguson, 2012; hooks, 1989; Seidel, 2019). Based on this awareness, a harm reduction pedagogy strives to form pathways that support the presence and success of people of color in higher education by emboldening White students and teachers to more critically understand and address the harmful impacts of our actions at the individual, interpersonal, communal, and institutional level. In this way, a harm reduction pedagogy endeavors to reduce the weight of racism and colonialism bearing down on teachers and students of color by giving White teachers and students the needed tools and motivation to redefine our relationship to Whiteness. In other words, harm reduction in this context is a redistribution of the physical, emotional, psychological, and spiritual labor and responsibility of refusing white supremacy.

Writing about feelings of depletion in the academy, Sara Ahmed (2013) defines privilege as an "energy-saving device" (para. 8) as something that reduces the effort required to get things done and get through the day. Privilege preserves the energy of White people (as well as enabled people) by transferring the work to racialized (and disabled) others, which explains why Jillian Carter Ford (2016) describes inequity and injustice as "energy lost" (p. 36). Unmaking privilege, then, is partially a matter of renegotiating expected energy use - of critically interrogating what power expects of us and how we can act and be with each other in more balanced ways. For harm is, from a certain perspective, a matter of energy. We experience harm more readily when our energy is depleted, because our energy is depleted, and we heal from harm through rest, or the recovering of energy. Harm reduction is about moving towards sustainable energy use by addressing the causes of depletion and by making opportunities for rest 
Journal Committed to Social Change on Race and Ethnicity | Volume 6, Issue 1 | 2020

in depleting institutions. An anti-racist disability justice pedagogy pursues this same objective when teachers and students work through difficult questions of accountability and access(ibility), which, as I will argue momentarily, are deeply entwined.

\section{Pedagogical Accountability and Accountability Planning}

A harm reduction pedagogy acknowledges first that White educators, even those devoted to anti-racist, decolonial teaching, cannot simply remove ourselves from participation in white supremacy and settler colonialism and, second, that we hold a vital responsibility to minimize and be accountable for the harm students of color encounter in our classrooms. Systems of power like White supremacy have a "gravitational pull" (Chris Crass, 1999, as cited in Russo, 2019, p. 21) that keeps us moving toward them, so that no matter the effort White educators put into anti-racism or solidarity with racial justice movements, we are ever vulnerable to their influence.

As a result, it is necessary for us to continually reflect on and increase our knowledge of pedagogical accountability. Accountability refers to a process of building equitable and just relationships, often across power and difference, that promote mutual well-being as we accept responsibility for our interdependence. To be accountable is to admit to and act from an awareness of how our survival and well-being are joined together with the survival and well-being of other peoples, which means that not loving and caring for others inevitably lessens our humanity and leads to even more harm. Pedagogical accountability is the acceptance of this responsibility in the contexts of teaching and learning - contexts wherein we have a heightened capacity to influence understandings of social justice and right action. 
Journal Committed to Social Change on Race and Ethnicity | Volume 6, Issue 1 | 2020

Practicing accountability as a White crip educator for me has meant, first and foremost, comprehending the intersectionality of disability oppression and its deeprooted connections to anti-Blackness, slavery, capitalism, empire, and other sources of racialized violence (Hedva, 2016; Lewis, 2019; Mingus, 2011b). I have come to understand that practicing accountability as a White crip educator yields its own unique challenges and obligations, for in claiming a position among the people harmed by and fundamentally opposed to ableism, I am also re-positioning myself relative to all the other systems and structures of dominance with which ableism is interlocking. In doing so, I shift the consequences of neglecting my Whiteness and my settler identity. I find it useful to think about accountability as action and movement precisely because of this continual re-positioning; if social justice can be described as moving against the gravitational pulls of supremacy, then so too can accountability be defined as moving towards the communities and peoples we are pulled away from. Del Hierro et al. (2016) argue that allyship/alliance, which I understand as holding shared meaning with accountability, "is not a state to be achieved, but a community-based process of making" (para. 3). Accountability, therefore, is not a checklist of predetermined items to be marked off (Price, 2011a), but something which we continuously re-create in a pursuit of togetherness. As our relationships evolve and our communities change, so too do our responsibilities to ourselves and one another.

In order to venture into a meaningful practice of accountability, we cannot just accept responsibilities in moments where harm presents itself. Instead, we must also anticipate harm, predict harm, plan for harm, and teach in a way that prevents or limits the impacts of harm. In my teaching, I utilize a process of accountability planning to 
Journal Committed to Social Change on Race and Ethnicity | Volume 6, Issue 1 | 2020

support harm reduction by figuring out how I can be accountable to students of color, including and particularly disabled students of color, as reliably and impactfully as is possible. Accountability planning is a way for me to recognize that harm is ordinarily present rather than present only in sporadic or exceptional moments. Furthermore, accountability planning helps me to recognize and embody Shannon Perez-Darby's (2011) wisdom that the joy of accountability begins with the self, that the first place we should critically examine is our own beliefs and actions. I cannot ask my students to practice accountability when I am living out of accountability and, therefore, failing to model it for them. The process of accountability planning keeps me conscious of and dedicated to disability justice because it encourages me to continuously reflect on how my actions can yield the conditions necessary for people to be present and cared for how I can help to establish the most accessible learning spaces for me and my students.

In practice, accountability planning is messy, painful, discomforting, and frustratingly incomplete, but so too is accountability - if it were easy, we would have fixed the world a long time ago. Accountability planning in its complexity reminds us that alliance, solidarity, and access are not reducible to checklists, even if checklists can be crucial (Piepzna-Samarasinha, 2018; Price, 2011a). Returning to Del Hierro et al.'s (2016) call to think about alliance as movement, accountability planning for me is not about producing some rigid set of responses to harm but, rather, about asking questions and exploring arduous situations that incite me to move in different ways with my students. Consequently, I am less interested in finding the one perfect answer to a 
Journal Committed to Social Change on Race and Ethnicity | Volume 6, Issue 1 | 2020

harmful situation than I am in understanding my responsibilities to act or hold space as an anti-racist White crip educator.

In addition, accountability planning is not catastrophic thinking wherein I imagine the worst possible scenario and make myself out to be a hero; rather, it is preparation for the everyday realities of white supremacy and disability oppression. It is about noting spaces where I can turn off and turn down the "energy-saving device" (Ahmed, 2013, para. 8) that is my white privilege so that students of color might find some degree of rest in my classes. This noting can include everything from finding places to talk about common racial microaggressions with White students, to teaching against the erasure of Indigeneity and the denial of Black and Brown intellectuals, to deconstructing the assumption that disability oppression only affects White people, to the enragingly frequent need to remind White students to think about race at all. Depending on the situation, I may physically write these things down or I may just keep them in mind, and I will encourage my students to do the same.

I find accountability planning useful as a White crip educator because it helps me more fully understand the purposes and actions that are required of me to implement an anti-racist disability justice pedagogy. Actually, developing a habit of accountability planning has helped me to comprehend that access needs are much more complex than white disability studies and mainstream disability movements often make space for. Indeed, if we return to Talila Lewis' (2019) definition of ableism as a system rooted in anti-Blackness, Patricia Berne's rooting of disability oppression in colonial Western European expansion (Sins Invalid 2016), and Mingus' (2011a) description of the connections between ableism and multiple other systems and structures of oppression, 
Journal Committed to Social Change on Race and Ethnicity | Volume 6, Issue 1 | 2020

then our thinking about what it means to make a space accessible has to be both nuanced and intersectional. We have to contemplate the interlocking, colliding histories of disability oppression and white supremacy that lead to particular modes of inaccessibility. If ableism and sanism are grounded in anti-Blackness and slavery and eugenics and settler colonialism, then how we go about promoting access today must be embedded in the refusal of those things. For how can a space be "accessible" if it promotes, even unintentionally, the death, incarceration, displacement, etc., of students of color? It cannot be and we should not pretend that it is. To do so is to accept the mantle of whiteness violently bestowed upon us, but to seek out something more transgressive and collectively empowering is the path to disability justice.

\section{Conclusion}

Among other solidarities and commitments, practicing disability justice in pedagogy means challenging white supremacy through anti-racist teaching and action. White crip teachers have a vital responsibility to show up for students of color, many of whom are themselves disabled with their own unique access needs and histories of experiences with racialized ableism and racialized sanism. Disability justice as a critical framework and social justice movement was developed by queer and trans disabled people of color, and its principles state the need for intersectionality, solidarity, and collective liberation (Mingus, 2014; Sins Invalid, 2016). Building a pedagogy from disability justice means integrating these principles into our teaching and learning spaces, which ultimately means that we must commit to resisting white supremacy and many other systems of power and oppression. 
Journal Committed to Social Change on Race and Ethnicity | Volume 6, Issue 1 | 2020

Without doing this, we cannot love all our disabled students, nor can we make our classes accessible to them because of our internalized and unquestioned dominance. However, ensuring that disability pedagogies are committed to anti-racism and decolonization will only make us better teachers that can genuinely care about and for our students in celebration of their differences and in recognition of their unique struggles. Disability justice makes this caring possible, and it is up to each of us to realize it. 
Journal Committed to Social Change on Race and Ethnicity | Volume 6, Issue 1 | 2020

\section{References}

Ahmed, S. (2013 November 17). Feeling depleted. Retrieved from FeministKilljoys: https://feministkilljoys.com/2013/11/17/feeling-depleted/

Ahmed, S. (2017). Living a Feminist Life. Duke University Press.

Annamma, S. A., \& Handy, T. (2019). DisCrit solidarity as curriculum studies and transformative praxis. Curriculum Inquiry: Disability as Meta Curriculum:

Epistemologies, Ontologies, and Transformative Praxis, 49(4), 442-463. https://doi.org/10.1080/03626784.2019.1665456

Bell, C. (2017). Is disability studies actually White disability studies? In L. Davis (ed.), The Disability Studies Reader (pp. 406-415). Routledge.

Clare, E. (1999). Exile and pride: Disability, queerness, and the liberation. Duke University Press.

Clare, E. (2017). Brilliant imperfection: Grappling with cure. Durham: Duke University Press.

Crass, C. (2013). Towards collective liberation: Anti-racist organizing, feminist praxis, and movement-building strategy. PM Press.

Del Hierro, V., Levy, D., \& Price, M. (2016). We are here: Negotiating difference and alliance in spaces of cultural rhetorics. Enculturation: http://enculturation.net/weare-here

Duncan, P. (2014). Hot commodities, cheap labor: Women of color in the academy. Frontiers: A Journal of Women's Studies, 35(3), 39-63.

Ferguson, $\mathrm{R}$ (2012). The reorder of things: The university and its pedagogies of minority difference. University of Minnesota Press.

Ford, J.C. (2016). "I'm feelin' it": Embodied spiritual activism as a vehicle for queer Black liberation. In B. Berila, M. Klein, and C.J. Roberts (eds.), Yoga, the body, and embodied social change (pp. 29-40). Lexington Books.

Freire, P. (2000). Pedagogy of the oppressed. New York: Bloomsbury. (Original work published 1970).

Garland-Thompson, R. (2002). Integrating disability, transforming feminist theory. National Women's Studies Association Journal, 14(2), 1-32.

Hedva, J. (2016). Sick woman theory. Mask Magazine: http://www.maskmagazine.com/not-again/struggle/sick-woman-theory.

hooks, b. (1989). Talking back: Thinking feminist, thinking Black. Boston: South End Press.

hooks, b. (1994). Teaching to transgress: Education as the practice of freedom. Routledge.

Kafer, A. (2013). Feminist, queer, crip. Indiana University Press.

Kandaswamy, P. (2007). Beyond colorblindness and multiculturalism: Rethinking antiracist pedagogy in the university classroom. Radical Teacher, 80, 6-11.

Koyama, E. (2001). Toward a harm reduction approach in survivor advocacy. Eminism.org: https://eminism.org/readings/harmreduction.html

Levins Morales, A. (2013). Kindling: Writings on the body. Cambridge: Palabrera Press.

Lewis, T. (2019). Longmore Lecture: Context, clarity, and grounding. TalilaLewis.com: https://www.talilalewis.com/blog

Love, B. (2019). Dear White Teachers: You Can't Love Your Black Students If You Don't Know Them. Education Week: 
Journal Committed to Social Change on Race and Ethnicity | Volume 6, Issue 1 | 2020

https://www.edweek.org/ew/articles/2019/03/20/dear-white-teachers-you-cantlove-your.html

Meekosha, H. (2011). Decolonising disability: Thinking and acting globally. Disability \& Society, 26(6), 667-682. https://doi.org/10.1080/09687599.2011.602860

Mingus, M. (2011a, May 5). Access intimacy: The missing link. Leaving Evidence: https://leavingevidence.wordpress.com/2011/05/05/access-intimacy-the-missinglink/

Mingus, M. (2011b, August 21). Moving toward the ugly: A politic beyond desirability. Leaving Evidence. https://leavingevidence.wordpress.com/2011/08/22/movingtoward-the-ugly-a-politic-beyond-desirability/

Mingus, M. (2014). Reflection toward practice: Some questions on disability justice. In C. Wood (ed.), Criptiques (pp. 107-114). May Day Publishing.

Mingus, M. (2017 April 12). Access intimacy, interdependence and disability justice. Leaving Evidence. https://leavingevidence.wordpress.com/2017/04/12/accessintimacy-interdependence-and-disability-justice/

Perez-Darby, S. (2011). The secret joy of accountability: Self-accountability as a building block for change. In C. Chen, J. Dulani, and L.L. Piepzna-Samarasinha (eds.), The revolution starts at home: Confronting intimate violence within activist communities (pp. 101-114). Brooklyn: South End Press.

Piepzna-Samarasinha, L.L. (2018). Care work: Dreaming disability justice. Arsenal Pulp Press.

Price, M. (2011a June 18). Cripping revolution: A crazed essay [Plenary]. Society for Disability Studies. San Jose, CA.

Price, M. (2011b). Mad at school: Rhetorics of mental disability and academic life. University of Michigan Press.

Russo, A. (2019). Feminist accountability: Disrupting violence and transforming power. New York University Press.

Seidel, J. (2019). Life. Frayed. Journal of Curriculum Theorizing, 34(1), 117-122.

Sins Invalid (2016). Skin, tooth, and bone. The basis of movement is our people: A disability justice primer. Sins Invalid: https://www.sinsinvalid.org/disability-justiceprimer.

Slater, J., and Liddiard, K. (2018). Why disability studies scholars must challenge transmisogyny and transphobia. Canadian Journal of Disability Studies, 7(2), 8393. 